\title{
BACTERIOLOGICAL CULTURE OF ENDOTRACHEAL ASPIRATES: A SIMPLE DIAGNOSTIC TOOL AND A GUIDE FOR EMPIRIC ANTIBIOTIC THERAPY IN SUSPECTED CASES OF VENTILATOR-ASSOCIATED PNEUMONIA
}

\author{
Swathi Vijaykumar', Narendra Padmanabha Nayak2, Sanchita Shettigar ${ }^{3}$, Yashwanth Rai ${ }^{4}$
}

1 Infection Control Supervisor, Department of Microbiology, Dr. Sulaiman Al Habib Hospital, Al Qassim, Kingdom of Saudi Arabia. 2Professor, Department of Microbiology, A. J. Institute of Medical Sciences and Research Centre, Mangalore, Karnataka.

${ }_{3}^{3}$ Assistant Professor, Department of Microbiology, A. J. Institute of Medical Sciences and Research Centre, Mangalore, Karnataka. ${ }_{4}^{4}$ Associate Professor, Department of Microbiology, A. J. Institute of Medical Sciences and Research Centre, Mangalore, Karnataka.

\begin{abstract}
BACKGROUND

Ventilator Associated Pneumonia (VAP) contributes majorly for increasing morbidity and mortality in patients on ventilator. Its incidence increases with the duration of mechanical ventilation. Hence, it requires a rapid diagnosis and initiation of an appropriate antibiotic therapy, if not it will lead to emergence of drug resistant pathogens and poor prognosis in these patients.

AIMS

To confirm VAP by Clinico-Pulmonary Infection Score. To assess the spectrum of aerobic bacteria in endotracheal aspirates of patients on ventilator. To evaluate the antibiotic sensitivity pattern of the isolates and detection of Extended-Spectrum $\beta$ Lactamase (ESBL) production in Escherichia coli and Klebsiella pneumoniae. To guide the clinicians in formulating an appropriate antibiotic policy, which will help prevent the emergence of multidrug resistant strains in MICU.
\end{abstract}

\section{SETTINGS AND DESIGN}

An observational cross-sectional study.

\section{METHODS}

The study enrolled 110 patients on mechanical ventilator for $>48$ hours, in MICU for 1 year. Semi-quantitative cultures of endotracheal aspirates were done to differentiate colonizers from pathogens and a count of $\geq 10^{5}$ colony forming units/millilitre was considered significant.

\section{RESULTS}

Ventilator associated infection rate was found to be $16.67 / 1000$ ventilator days. The incidence of aerobic gram negative bacteria was $84.6 \%$ predominantly, Pseudomonas aeruginosa and Klebsiella pneumoniae followed by Acinetobacter species. Among the gram positive isolates (15.4\%), Staphylococcus aureus was most common followed by Streptococcus species. Pseudomonas and Acinetobacter were multi-drug resistant with relatively higher sensitivity to $\beta$ lactam- $\beta$ lactamase inhibitor combinations, carbapenems and aminoglycosides. ESBL production was detected amongst K. pneumoniae and Escherichia coli by phenotypic confirmatory disc diffusion test; $53.8 \% \mathrm{~K}$. pneumoniae isolates and $50 \%$ E. coli isolates showing significant growth were ESBL producers. S. aureus showed methicillin resistance in $28.6 \%$ of the isolates and $100 \%$ sensitivity to vancomycin, linezolid and clindamycin.

\section{STATISTICS USED}

SAS 9.2, SPSS 15.0, Stata 10.1, MedCalc 9.0.1, Systat 12.0 and R environment Ver. 2.11.1.

\section{CONCLUSION}

This study provides a baseline data of the present scenario of VAP in our hospital, which can help formulate infection control strategies. There is also a need for prospective studies in India to prevent these infections in ICUs.

\section{KEYWORDS}

Endotracheal Aspirates; Semi-Quantitative Culture; Gram Negative Bacteria, Ventilator.

HOW TO CITE THIS ARTICLE: Vijaykumar S, Nayak NP, Shettigar S, et al. Bacteriological culture of endotracheal aspirates: a simple diagnostic tool and a guide for empiric antibiotic therapy in suspected cases of ventilator-associated pneumonia. J. Evolution Med. Dent. Sci. 2016;5(74):5445-5450, DOI: 10.14260/jemds/2016/1233

Financial or Other, Competing Interest: None.

Submission 09-08-2016, Peer Review 01-09-2016,

Acceptance 08-09-2016, Published 14-09-2016.

Corresponding Author:

Dr. Swathi Vijaykumar,

"Tulasi Nilaya," Opposite Government School,

K. R. Puram Extension,

Shimoga-577201, Karnataka.

E-mail: swathivrao28@gmail.com

DOI: $10.14260 /$ jemds/2016/1233

\section{INTRODUCTION}

Hospital-acquired infections are of great concern, both to the patients and to the treating clinicians, as these infections have limited therapeutic options due to the presence of multi-drug resistant strains in the hospital. The principal components of a hospital such as patients, health-care personnel, equipment and indwelling devices employed for the patients and the microbial population in the hospital environment are the main sources of these infections. Each unit of a hospital will have a particular nosocomial infection related to the type of patient being admitted, their underlying illnesses, procedures 
employed and the selection pressure exerted due to indiscriminate use of antibiotics on the microorganisms.

Ventilator Associated Pneumonia (VAP) is one such nosocomial infection seen in Intensive Care Units (ICUs). VAP is defined as nosocomial pneumonia developing in a patient on mechanical ventilator after 48 hours of intubation or within 48 hours of extubation. 1,2 There are two categories of VAP - early onset and late onset. Early onset VAP occurs within 96 hours of ventilation and late onset VAP occurs after 96 hours of ventilation. This categorisation helps to predict the implicated pathogens and guides us in the initial empiric therapy with antibiotics. 3,4

Early-onset pneumonia commonly results from aspiration of endogenous, community-acquired pathogens colonising the oropharynx and impaired consciousness. Conversely, late-onset VAP is caused by more unusual or MultidrugResistant (MDR) pathogens following aspiration of oropharyngeal and gastric secretions. ${ }^{5,6}$

Since VAP is a major contributor for the increasing morbidity and mortality in patients on ventilator, it requires a rapid diagnosis and initiation of an appropriate antibiotic therapy. Inappropriate and inadequate antibiotic treatment will lead to emergence of drug resistant pathogens and poor prognosis in patients on ventilator.

Quantitative or semi-quantitative culture from endotracheal aspirates is a non-invasive, feasible and relatively easier method for the microbiological diagnosis of VAP than any other invasive techniques like bronchoalveolar lavage, protective specimen brushing and lung biopsy, which are commonly associated with risk of complications during the procedure. 7,8

So this study was undertaken to know the above mentioned parameters and guide the clinicians in formulating an appropriate antibiotic policy. This will help prevent the emergence of multidrug resistant strains in MICU.

\section{AIMS}

- To assess the spectrum of aerobic bacteria in endotracheal aspirates of patients on ventilator.

- To evaluate the antibiotic sensitivity pattern in the isolates and detection of Extended Spectrum BLactamase (ESBL) production in Escherichia coli and Klebsiella species.

- To correlate the clinical findings with the bacterial isolates as a probable cause of ventilator associated pneumonia by using modified Clinico-Pulmonary Infection Score (m-CPIS).

\section{MATERIAL AND METHODS}

\section{Source of Data}

Patients on ventilator admitted in M.I.C.U during the period from November 2012 to October 2013.

\section{Method}

A cross-sectional study of 1-year duration involving 110 samples of endotracheal aspirates from patients on ventilator was done, to ascertain the profile of the aerobic bacteria in them ${ }^{9-13}$ and to study their antibiotic sensitivity pattern. Clinical assessment of the patients was done only after obtaining an informed consent regarding the nature of the study from their relatives.

\section{Inclusion Criteria}

- $\quad$ Patients $>/=18$ years.

- $\quad$ Ventilated for $>/=48 \mathrm{hrs}$.

\section{Exclusion Criteria}

- $\quad$ Patients $<18$ years.

- Ventilated for $<48 \mathrm{hrs}$.

- Severely immunocompromised states - AIDS, organ transplant patients, terminal stages of malignancy, etc.

- Patients diagnosed to have pneumonia prior to intubation.

Endotracheal aspirate was collected using a sterile 21-inch Romsons' 14FG suction catheter with a sterile mucus extractor under aseptic precautions. The catheter was withdrawn and approximately $2 \mathrm{~mL}$ of sterile normal saline was injected into it with a sterile syringe to flush the exudate into a sterile container, which was immediately transported to the Microbiology Department for processing. ${ }^{14,15}$

A smear was prepared from the sample and Gram staining was done. The sample was then mechanically liquefied and homogenised by vortexing for a minute. Using a standard wire loop $\left(0.001 \mathrm{~mL}\right.$, semi-quantitative $\left.\operatorname{method}^{7,8}\right)$, it was inoculated onto MacConkey agar, Blood agar and Chocolate agar plates and incubated at $37^{\circ} \mathrm{C}$ for $24 \mathrm{hrs}$. to $48 \mathrm{hrs}$.

A positive Gram stain 16-19 $\quad>10$ polymorphonuclear cells/low power field and $>/=1$ bacteria/oil immersion field ${ }^{20,21}$ ) and a colony count of $10^{5} \mathrm{CFUs} / \mathrm{mL}$ or more was considered significant. Identification of the organisms was done by various biochemical tests as per the Clinical Laboratory Standards Institute (CLSI) guidelines. ${ }^{22}$

Antibiotic susceptibility testing was done by Kirby Bauer's disc diffusion method using commercially available discs (HiMedia Laboratories) on Mueller Hinton agar23,24 and also ESBL production in E. coli and Klebsiella species was detected by phenotypic confirmatory disc diffusion test using ceftazidime and combination of ceftazidime and clavulanic acid discs according to CLSI guidelines. ${ }^{22}$ ATCC strains of E. coli 25922 and K. pneumoniae ATCC 700603 was used as quality control strains for the detection of ESBL production.

VAP was diagnosed by using modified clinico-pulmonary infection score by Singh et al (Table 1). They observed that the empiric antibiotic treatment could be stopped on day 3 , if the scoring on $\mathrm{m}$-CPIS is $<6$ and can be continued for the entire course if $\mathrm{m}$-CPIS is $>6.25$

\begin{tabular}{|c|c|}
\hline Parameters & Points \\
\hline \multicolumn{2}{|l|}{ 1. Temperature $\left({ }^{0} \mathrm{C}\right)$} \\
\hline $36.5-38.4^{\circ} \mathrm{C}$ & 0 \\
\hline $38.5-38.9^{\circ} \mathrm{C}$ & 1 \\
\hline$<36.0^{\circ} \mathrm{C}$ or $>39.0^{\circ} \mathrm{C}$ & 2 \\
\hline 2. WBC (cells/mm3) & \\
\hline $4000-11,000$ & 0 \\
\hline$<4000$ or $>11,000$ & 1 \\
\hline Band forms $>50 \% \mathrm{WBC}$ & 2 \\
\hline \multicolumn{2}{|l|}{ 3. Sputum } \\
\hline No sputum & 0 \\
\hline Non-purulent sputum & 1 \\
\hline Purulent sputum & 2 \\
\hline 4. Oxygenation: $\mathrm{PaO}_{2} / \mathrm{FIO}_{2}(\mathrm{mmHg})$ & \\
\hline$>240$ or presence of $\mathrm{ARDS}\left(\mathrm{PaO}_{2} / \mathrm{FIO}_{2}<200\right.$ or & 0 \\
\hline PAWP $<18 \mathrm{mmHg}$ plus & \\
\hline
\end{tabular}




\begin{tabular}{|c|c|}
\hline new chest infiltrate) & \\
\hline$</=240$ and no ARDS & 2 \\
\hline 5. CXR & 0 \\
\hline No infiltrate & 1 \\
\hline Diffuse or patchy infiltrate & 2 \\
\hline Localised infiltrate & 0 \\
\hline 6. Progression of infiltration from CXR & 2 \\
\hline No infiltrate progression & 0 \\
\hline Infiltrate progression (no ARDS or CHF) & 1 \\
\hline 7. Culture from tracheal aspirate & 2 \\
\hline $\begin{array}{c}\text { Moderate or heavy growth of } \\
\text { pathogenic bacteria }\end{array}$ & \\
\hline $\begin{array}{c}\text { Growth of pathogenic bacteria } \\
\text { similar to that from Gram stain }\end{array}$ \\
\hline $\begin{array}{c}\text { Table 1*: Modified Clinico-Pulmonary } \\
\text { Infection Score (M-CPIS) by Singh } \text { et al }\end{array}$ \\
\hline or rare growth of pathogenic bacteria \\
\hline
\end{tabular}

[*-ARDS: Adult Respiratory Distress Syndrome, PAWP: Pulmonary Artery Wedge Pressure, $\mathrm{PaO}_{2} / \mathrm{FIO}_{2}$ : arterial oxygen pressure divided by fraction of inspired oxygen, CXR: Chest X-Ray, CHF: Congestive Heart Failure]. Ventilator associated infection rate was calculated by the following formula. ${ }^{26}$

$$
\text { Infection rate }=\frac{\text { Number of patients developing VAP }}{\text { Total number of ventilator days }}^{\text {X } 1000}
$$

Expressed as "number of ventilator associated infection per 1000 ventilator days."

\section{RESULTS}

\section{Study Design}

An observational cross-sectional clinical study after getting an ethical clearance from Ethics Committee.

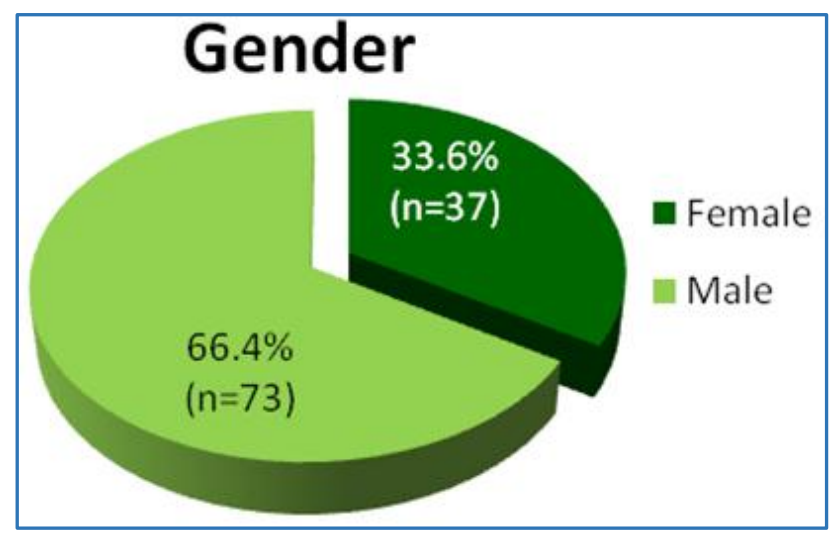

Fig. 1: Gender Distribution of Patients Studied

\begin{tabular}{|c|c|c|}
\hline $\begin{array}{c}\text { Duration of } \\
\text { Ventilation (In Days) }\end{array}$ & $\begin{array}{c}\text { No. of } \\
\text { Patients }\end{array}$ & $\mathbf{\%}$ \\
\hline $1-2$ & 0 & 0.0 \\
\hline $3-5$ & 67 & 60.9 \\
\hline $6-10$ & 40 & 36.4 \\
\hline$>10$ & 3 & 2.7 \\
\hline Total & $\mathbf{1 1 0}$ & $\mathbf{1 0 0 . 0}$ \\
\hline Table 2: Duration of Ventilation of Patients in the Study \\
\hline
\end{tabular}

Mean \pm SD: $5.55 \pm 1.69$

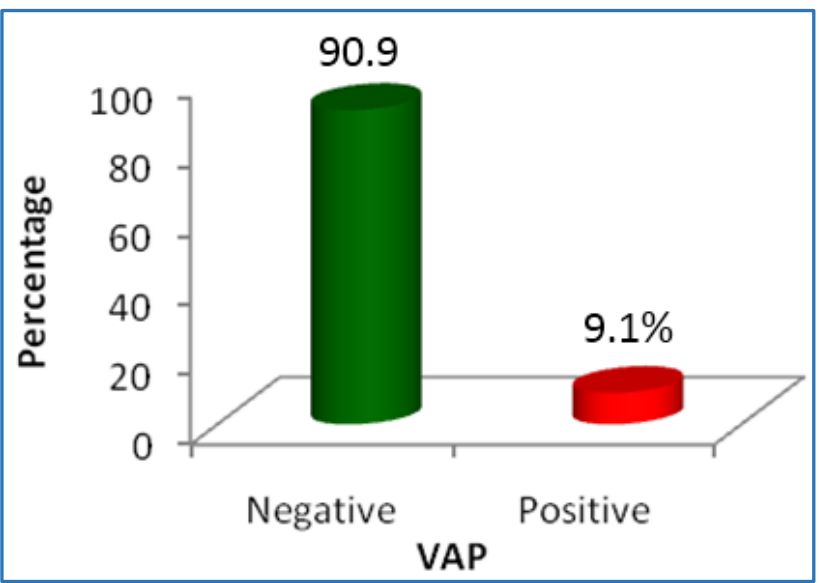

Fig. 2: Ventilator Associated Pneumonia According to CPIS

\section{Outcome of patients on ventilator}

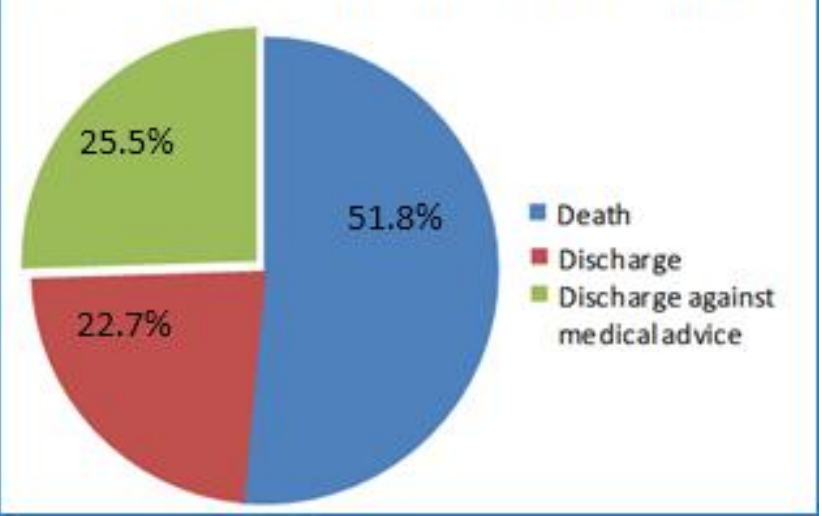

Fig. 3: Outcome of Patients on Ventilator

\begin{tabular}{|c|c|c|c|c|c|c|c|c|c|c|}
\hline \multirow[t]{2}{*}{ Antibiotic } & \multicolumn{2}{|c|}{$\begin{array}{c}\text { Acinetobacter } \\
\text { (n=11) }\end{array}$} & \multicolumn{2}{|c|}{$\begin{array}{c}\text { Pseudomonas } \\
(\mathrm{n}=13)\end{array}$} & \multicolumn{2}{|c|}{$\begin{array}{c}\text { K. pneumoniae } \\
(\mathrm{n}=13)\end{array}$} & \multicolumn{2}{|c|}{$\begin{array}{l}\text { E. coli } \\
(n=4)\end{array}$} & \multicolumn{2}{|c|}{$\begin{array}{c}\text { C. freundii } \\
(n=3)\end{array}$} \\
\hline & $\mathbf{R}$ & $S$ & $\mathbf{R}$ & $S$ & $\mathbf{R}$ & $S$ & $\mathbf{R}$ & $S$ & $\mathbf{R}$ & $S$ \\
\hline Amp & -- & -- & -- & -- & -- & -- & 2 & 0 & 0 & 0 \\
\hline Amc & 2 & 0 & -- & -- & 7 & 6 & 2 & 0 & 3 & 0 \\
\hline $\mathrm{Ak}$ & 8 & 2 & 0 & 13 & 4 & 9 & 4 & 0 & 3 & 0 \\
\hline At & 9 & 2 & 0 & 13 & 4 & 9 & 4 & 0 & 3 & 0 \\
\hline Cpm & 10 & 0 & 5 & 8 & 9 & 4 & 4 & 0 & 3 & 0 \\
\hline Cfs & 9 & 2 & 5 & 8 & 6 & 7 & 2 & 2 & 3 & 0 \\
\hline Caz & 10 & 0 & 2 & 11 & 9 & 4 & 4 & 0 & 3 & 0 \\
\hline $\mathrm{Ctx} / \mathrm{Ctr}$ & 10 & 0 & 5 & 8 & 9 & 4 & 4 & 0 & 3 & 0 \\
\hline Cip & 9 & 1 & 4 & 9 & 6 & 6 & 4 & 0 & 3 & 0 \\
\hline Cot & 10 & 1 & 6 & 7 & 4 & 9 & 4 & 0 & 3 & 0 \\
\hline Gen & 7 & 3 & 3 & 10 & 4 & 9 & 4 & 0 & 3 & 0 \\
\hline $\mathrm{Ipm}$ & 2 & 9 & 0 & 13 & 2 & 11 & 0 & 4 & 0 & 3 \\
\hline Le & 10 & 1 & 3 & 10 & 5 & 7 & 4 & 0 & 3 & 0 \\
\hline Mrp & 6 & 4 & 3 & 10 & 6 & 7 & 0 & 2 & 3 & 0 \\
\hline Of & 9 & 1 & 3 & 9 & 7 & 6 & 4 & 0 & 3 & 0 \\
\hline $\mathrm{Pi}$ & 10 & 0 & 5 & 8 & 6 & 7 & 4 & 0 & 3 & 0 \\
\hline Pit & 9 & 1 & 3 & 10 & 3 & 10 & 2 & 2 & 3 & 0 \\
\hline $\mathrm{Te}$ & 9 & 2 & 6 & 7 & 2 & 11 & 4 & 0 & 3 & 0 \\
\hline Tob & 9 & 2 & 9 & 4 & 4 & 9 & 4 & 0 & 3 & 0 \\
\hline ESBL & -- & -- & $\begin{array}{ll}-- \\
\end{array}$ & -- & & 7 & 2 & & \begin{tabular}{|l|}
-- \\
\end{tabular} & -- \\
\hline & & & & Tab & & & & & & \\
\hline
\end{tabular}

Table 3

Gram negative bacteria (With significant counts) susceptibility pattern. Antibiotic susceptibility testing was done according to CLSI guidelines, a part of which forms our hospital antibiotic policy. Our study tested all the antibiotics recommended by CLSI guidelines for the respective 
organisms, so that it could help to formulate a better timely empiric antibiotic therapy in suspected cases of VAP.

(*:Amp-Ampicillin, Amc-Amoxicillin Clavulanic acid, AkAmikacin, At-Aztreonam, Cpm-Cefepime, Cfs-Cefoperazonesulbactam, Caz-Ceftazidime, Ctx/CtrCefotaxime/Ceftriaxone, Cip-Ciprofloxacin, CotCotrimoxazole, Gen-Gentamicin, Ipm-Imipenem, LeLevofloxacin, Mrp-Meropenem, Of-Ofloxacin, Pi-Piperacillin, Pit-Piperacillin Tazobactam, Tob-Tobramycin)

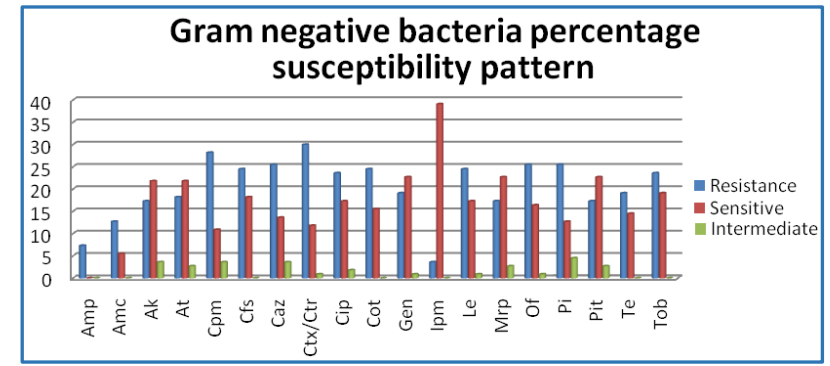

\section{Fig. 4: Overall Susceptibility Pattern of Gram Negative Bacteria with Significant Counts for Different Antimicrobials*}

(*:Amp-Ampicillin, Amc-Amoxicillin Clavulanic acid, AkAmikacin, At-Aztreonam, Cpm-Cefepime, Cfs-Cefoperazonesulbactam, Caz-Ceftazidime, Ctx/CtrCefotaxime/Ceftriaxone, Cip-Ciprofloxacin, CotCotrimoxazole, Gen-Gentamicin, Ipm-Imipenem, LeLevofloxacin, Mrp-Meropenem, Of-Ofloxacin, Pi-Piperacillin, Pit-Piperacillin Tazobactam, Tob-Tobramycin)

\begin{tabular}{|c|c|c|c|c|c|c|}
\hline \multirow{2}{*}{$\begin{array}{c}\text { Gram } \\
\text { Positive } \\
\text { Cocci }\end{array}$} & \multicolumn{3}{|c|}{$\begin{array}{l}\text { Staphylococcus } \\
\text { Aureus (n=7) }\end{array}$} & \multicolumn{3}{|c|}{$\begin{array}{l}\text { Streptococcus } \\
\text { Species }(n=1)\end{array}$} \\
\hline & R (\%) & S (\%) & I (\%) & R (\%) & S (\%) & I (\%) \\
\hline Amp & -- & -- & -- & 0 & 100 & 0 \\
\hline $\mathrm{Cx}$ & 28.6 & 71.4 & 0 & -- & -- & -- \\
\hline Cip & 0 & 57.1 & 42.9 & 0 & 100 & 0 \\
\hline $\mathrm{Cd}$ & 0 & 100 & 0 & 0 & 100 & 0 \\
\hline Cot & 0 & 100 & 0 & 100 & 0 & 0 \\
\hline $\bar{E}$ & 0 & 100 & 0 & 0 & 100 & 0 \\
\hline Gen & 28.6 & 71.4 & 0 & 0 & 0 & 100 \\
\hline Le & 0 & 100 & 0 & 0 & 100 & 0 \\
\hline $\mathrm{Lz}$ & 0 & 100 & 0 & 0 & 100 & 0 \\
\hline Of & 0 & 100 & 0 & 0 & 100 & 0 \\
\hline $\mathrm{P}$ & 57.1 & 42.9 & 0 & 0 & 100 & 0 \\
\hline $\mathrm{Te}$ & 0 & 100 & 0 & 0 & 100 & 0 \\
\hline $\mathrm{Va}$ & 0 & 100 & 0 & 0 & 100 & 0 \\
\hline \multicolumn{7}{|c|}{$\begin{array}{l}\text { Table 4: Gram Positive Cocci with } \\
\text { Significant Counts Susceptibility Pattern }\end{array}$} \\
\hline
\end{tabular}

(*:Amp-Ampicillin, Cx-Cefoxitin, Cip-Ciprofloxacin, CdClindamycin, Cot-Cotrimoxazole, E-Erythromycin, GenGentamicin, Le-Levofloxacin, Lz-Linezolid, Of-Ofloxacin, PPenicillin, Te-Tetracycline, Va-Vancomycin)

\section{Statistical Methods}

Descriptive and inferential statistical analysis has been carried out in the present study. Results on continuous measurements are presented on Mean \pm SD (Min-Max) and results on categorical measurements are presented in Number (\%). Significance is assessed at 5\% level of significance.

\section{Statistical Software}

The Statistical software namely SAS 9.2, SPSS 15.0, Stata 10.1, MedCalc 9.0.1, Systat 12.0 and R environment Ver. 2.11.1 have been used for the analysis of the data and Microsoft Word and Excel to generate graphs, tables, etc.

\section{DISCUSSION}

In the present study, it was found that $66.4 \%$ of the cases on ventilator were males and $33.6 \%$ were females (Figure 1). The male predominance can be attributed to high prevalence in males of other co-morbid conditions, risk factors like COPD and higher rates of Road Traffic Accidents (RTA).

The incidence of VAP differs depending on the type of hospital or ICU, the population studied and the organisms prevalent; and in our study ventilator associated infection rate is found to be " 16.67 per 1000 ventilator days." The incidence of VAP is $9.1 \%$ (Figure 2), which is similar to a few studies by Cook DJ et al, Apostolopoulou E et al and Rosenthal VD et al, where the rate had varied from $7 \%$ to $70 \% .^{9-11}$

In a prospective study conducted in South India (2006), Arindam Dey et al reported the incidence of VAP to be $45.4 \% .{ }^{27}$ In another study, Girish L Dandagi et al (2005) reported the incidence to be $45 \% .{ }^{28}$ Trivedi et al (2000) in Mumbai, reported an incidence of $9.38 \%$ of nosocomial pneumonia and $38 \%$ had ventilator associated pneumonia. 29 Rakshit et al (2005) in Mumbai reported an incidence of $47 \%{ }^{30}$

The organisms responsible for VAP vary according to case, institution, prior antibiotic exposure, local resistance patterns, length of mechanical ventilation and specific diagnostic methods used. In our study, the incidence of aerobic gram negative bacteria (Table 3 ) was $80.6 \%$ with Pseudomonas aeruginosa and Klebsiella pneumoniae (25\%) as the predominant isolates followed by Acinetobacter species $(21.15 \%)$. This high incidence correlates with other studies like the one conducted by Rosenthal et al (2006). ${ }^{31}$ Staphylococcus aureus (13.5\%) was commonest among the gram positives correlating with a study by Yaseen Arabi et al accounting for $6-58 \% .^{32}$ We have observed that $20 \%$ of the cases were polymicrobial. The incidence of these polymicrobial isolates is well comparable with other studies by Mukhopadhyay $\mathrm{C}$ et al and Rakshit et al, which varies from $10 \%$ to $53 \%$ between centers. 14,30

A proportion of the pathogens isolated were resistant to multiple drugs. The drugs which were found to be highly effective in our study were imipenem, piperacillintazobactam, cefoperazone-sulbactam, amikacin, gentamicin and levofloxacin for gram negative bacilli. K. pneumoniae and E. coli isolates showed ESBL production in 53.6\% and 50\% respectively (Table 3 and Figure 4). This shows that there must be a probable selection pressure exerted by the indiscriminate use of antibiotics on the organisms prevalent in hospitals and is an alarming threat posed to the treatment of patients in ICUs and also in other areas of the hospital. S. aureus showed methicillin resistance in $28.6 \%$ of the isolates. For gram positive cocci, effective drugs found were linezolid, vancomycin and clindamycin (Table 4). These antibiotic susceptibility patterns may help the clinician to choose the drugs for initial empirical therapy and definitive therapy in the later stages of VAP.

It was also noted that mortality rate among the VAP patients was $51.8 \%$ (Figure 5). The rate was significantly high 
in patients with multi-drug resistant organisms and longer duration of ventilation.

\section{CONCLUSION}

This cross-sectional study has addressed the incidence and microbiological profile of VAP in our tertiary care centre. It has used the more appropriate and feasible means of diagnosis by semi-quantitative cultures, which has been advocated by various other studies to differentiate pathogens from colonisers. VAP was diagnosed using CPIS score. Our study also has demonstrated that VAP is a frequent complication in the ICUs, which may pose an additional economic burden on the patients and their families. Due to associated risk factors and co-morbid conditions, individuals with advancing age showed a higher tendency to develop VAP.

Endotracheal aspirate samples have been found to be very useful in isolation of aetiological agents and should be sent to the Microbiology Laboratory at the earliest from a patient on mechanical ventilation for more than 48 hours. This will surely help to improve the outcome of VAP in terms of mortality and morbidity.

We emphasise on the need of knowledge among clinicians of common organisms responsible and their antibiotic susceptibility for judicious use of empiric broad-spectrum antibiotics in ICUs. Nosocomial infections can negate the benefits of even the best of medical care and infections due to drug resistant pathogens posing a major threat to individual as well as the community. Combined approaches using rational antibiotic therapy and educational programs will be immensely beneficial to combat drug resistance. Isolation practices, antibiotic policies, effective infection control surveillance, maintenance of epidemiological trends of infections and rapid molecular diagnostic methods will help reduce nosocomial infections including ventilator associated pneumonia.

\section{REFERENCES}

1. Chastre J, Fagon JY. Ventilator-associated pneumonia. Am J Respir Crit Care Med 2002;165(7):867-903.

2. Jourdain B, Novara A, Joly-Guillou ML, et al. Role of quantitative cultures of endotracheal aspirates in the diagnosis of nosocomial pneumonia. Am J Respir Crit Care Med 1995;152(1):241-6.

3. Campbell GD, Niederman MS, Broughton MA, et al.. Hospital-acquired pneumonia in adults: diagnosis, assessment of severity, initial antimicrobial therapy and preventive strategies. A consensus statement. American thoracic society. Am J Respir Crit Care Med 1995;153:1711-25.

4. Ewig S, Torres A, El-Ebiary M, et al. Bacterial colonization patterns in mechanically ventilated patients with traumatic and medical head injury. Incidence, risk factors and association with ventilator-associated pneumonia. Am J Respir Crit Care Med 1999;159(1):18898.

5. Ewig S, Bauer T, Torres A. The pulmonary physician in critical care 4: nosocomial pneumonia. Thorax 2002; 57(4):366-71.

6. Hunter JD. Ventilator-associated pneumonia. Postgrad Med J 2006;82(965):172-8.
7. Koenig SM, Truwit JD. Ventilator-associated pneumonia: diagnosis, treatment, and prevention.Clin Microbiol Rev 2006;19(4):637-57.

8. Fujitani S, Cohen-Melamed $\mathrm{MH}$, Tuttle RP, et al. Comparison of semi- quantitative endotracheal aspirates to quantitative non-bronchoscopic bronchoalveolar lavage in diagnosing ventilator-associated pneumonia. Respir Care 2009;54(11):1453-61.

9. Cook DJ, Walter SD, Cook RJ, et al. Incidence of and risk factors for ventilator-associated pneumonia in critically ill patients. Ann Intern Med 1998;129(6):433-40.

10. Apostolopoulou E, Bakakos P, Katostaras T, et al. Incidence and risk factors for ventilator-associated pneumonia in 4 multidisciplinary intensive care units in Athens, Greece. Respir Care 2003;48(7)681-8.

11. Rosenthal VD, Guzman S, Orellano PW. Nosocomial infections in medical-surgical intensive care units in Argentina: attributable mortality and length of stay. Am J Infect Control 2003;31(5):291-5.

12. Gadani H, Vyas A, Kar AK. A study of ventilator associated pneumonia: Incidence, outcome, risk factors and measures to be taken for prevention. Indian J Anaesth 2010;54(6):535-40.

13. Marquette $\mathrm{CH}$, Copin $\mathrm{MC}$, Wallet F, et al. Diagnostic tests for pneumonia in ventilated patients: prospective evaluation of diagnostic accuracy using histology as a diagnostic gold standard. Am J Respir Crit Care Med 1995;151(6):1878-88.

14. Mukhopadhyay C, Bhargava A, Ayyagari A. Role of mechanical ventilation \& development of multidrug resistant organisms in hospital acquired pneumonia. Indian J Med Res 2003;118:229-35.

15. Goel N, Chaudhary U, Aggarwal R, et al. Antibiotic sensitivity pattern of gram negative bacilli isolated from the lower respiratory tract of ventilated patients in the intensive care unit. Indian J Crit Care Med 2009;13(3):148-51.

16. Joseph NM, Sistla S, Dutta TK, et al. Ventilator-associated pneumonia in a tertiary care hospital in India: role of multi-drug resistant pathogens. J Infect DevCtries 2010;4(4):218-25.

17. Kaul S, Brahmadathan KN, Jagannati M, et al. One year trends in the gram-negative antibiotic susceptibility patterns in a medical intensive care unit in south India. IJMM 2007;25(3):230-5.

18. Singhal R, Mohanty S, Sood S, et al. Profile of bacterial isolates from patients with ventilator associated pneumonias in a tertiary care hospital in India. Indian J Med Res 2005;121(1):63-4.

19. Ahmed SM, Choudhary J, Ahmed M, et al. Treatment of ventilator associated pneumonia with piperacillintazobactum and amikacinvscefpime and levofloxacin: a randomized prospective study. Indian J Crit Care Med 2007;11(3):117-21.

20. Rajasekhar T, Anuradha $K$, Suhasini $T$, et al. The role of quantitative cultures of non-bronchoscopic samples in ventilator associated pneumonia. Indian J Med Microbiol 2006;24(2):107-13.

21. Cook D, Mandell L. Endotracheal aspiration in the diagnosis of ventilator-associated pneumonia. Chest 2000;117(4 Suppl 2):195S-7S. 
22. Clinical and Laboratory Standard Institute, performance standards for antimicrobial susceptibility testing, 21 st informational supplement, M100-S21. 2011;31(1):42107.

23. Rello J, Quintana E, Ausina V, et al. Incidence, etiology and outcome of nosocomial pneumonia in mechanically ventilated patients. Chest 1991;100(2):439-44.

24. Papazion L, Bregeon F, Thirion X, et al. Effect of ventilator-associated pneumonia on mortality and morbidity. Am J Respir Crit Care Med 1996;154(1):91-7.

25. Pugin J, Auckenthaler R, Mili N, et al. Diagnosis of ventilator associated pneumonia by bacteriologic analysis of bronchoscopic and non bronchoscopic blind bronchealveolor lavage fluid. Am Rev Respir Dis 1991;143(5 Pt 1):1121-9.

26. Singh S, Pandya Y, Patel R, et al. Surveillance of device associated infections at a teaching hospital in rural Gujarat, India. Indian J Med Microbiol 2010;28(4):342-7.

27. Dey A, Bairy I. Incidence of multidrug resistant organisms causing ventilator-associated pneumonia in a tertiary care hospital: a nine months prospective study. Annals of Thorac Med 2007;2(2):52-7.
28. Dandagi GL. Nosocomial pneumonia in critically ill patients. Lung India 2010;27(3):149-53.

29. Trivedi TH, Shejale SB, Yeolekar ME. Nosocomial pneumonia in medical intensive care unit. JAPI 2000;48(11):1070-3.

30. Rakshit P, Nagar VS, Deshpande AK. Incidence, clinical outcome and risk stratification of ventilator-associated pneumonia: a prospective cohort study. Indian J Crit Care Med 2005;9(4):211-6.

31. Rosenthal VD, Maki DG, Salomao R, et al. Device associated nosocomial infections in 55 intensive care units of 8 developing countries. Ann Intern Med 2006;145(8):582-91.

32. Arabi Y, Al-Shirawi N, Memish Z, et al. Ventilator associated pneumonia in adults in developing countries: a systematic review. International Journal of Infectious Diseases 2008;12(5):505-12. 